\title{
Understanding Online Consumer Stickiness in E-commerce Environment: A Relationship Formation Model
}

\author{
Haiping Wang ${ }^{1}$, Guona $\mathrm{Gu}^{2}$, Shihu $\mathrm{An}^{3}$ and Guangchun Zhou ${ }^{4}$ \\ ${ }^{1}$ School of insurance, Shandong University of Finance and Economics \\ 40 Shungeng Road, Jinan, Shandong Province, China, 250014 \\ ${ }^{2,3,4}$ Shandong University of Finance and Economics \\ 40 Shungeng Road, Jinan, Shandong Province, China, 250014 \\ ${ }^{1}$ lcwhp@163.com
}

\begin{abstract}
Consumers with online shopping experience often stick to some special websites. Does it mean that long-term relationships between consumers and the websites form? To solve the problem, this paper analyzed the belief and attitude factors influencing online consumer stickiness intention. Based on the relationships between belief-attitude-intention implied in TPB (Theory of Planned Behavior), according to Expectation-Confirmation theory and Commitment-trust theory, we developed a concept model on online consumer stickiness. Six research hypotheses derived from this model were empirically validated using a survey of online shoppers. SEM (Structure Equation Modeling) was as a data analysis method. The results suggest that online consumer stickiness intention is influenced by consumers' commitment to the website (e-vendors) and their overall satisfaction to the transaction process, and commitment's effect is stronger; in turn, both consumers' commitment and overall satisfaction are influenced by consumers' ongoing trust significantly; confirmation has a significant effect on overall satisfaction but has not the same effect on commitment. The findings show that the long-term relationships between consumers and special websites exactly exist during online repeat consumption.
\end{abstract}

Keywords: online consumer stickiness, ongoing trust, commitment, confirmation, relationship

\section{Introduction}

Network technology has been integrated into every aspect of our daily life, such as shopping online, chatting online, listening music online and watching films online et al. More and more people have got accustomed to shopping online and enjoyed its pleasure. This also brings new marketing channel for businesses. So B2C e-commerce has made rapid development in China in recent years. Only in November 11, 2013, a famous company offering online trading platform named Alibaba records 35 billion RMB trading volume. Gradually it appears a certain "addiction" phenomenon in consumers shopping online. That is, they like logging on a website and repurchasing continuously. Especially they prefer some websites and frequently access or continue shopping just as if these websites have unique charms to attract them. These websites involve Jingdong Mall (jd.com), Taobao.com, Dangdang.com, Vip.com etc. Even if a lot of money is spent, they are still willing to continue shopping in the same website. What is the reason behind this phenomenon? What factors lead to this phenomenon? We will discuss these in this paper. 
It is often called user stickiness in the area of information system or other similar areas of network application. In marketing literature, it is often called consumer stickiness for those consumption features on consumers frequently visiting a website or shopping online over a period of time. The capability of making consumers sticky which the website has is called website stickiness [1]. Some literatures define the concept from different perspectives. Dahui $\mathrm{Li}$, Glenn J. Browne, and James C. Wetherbe give a definition from a user's perspective as follows: a user's repetitive visits to and use of a preferred website because of a deeply held commitment to reuse the website consistently in the future, despite situational influences and marketing efforts that have the potential to cause switching behavior [2]. Furthermore, Ling Xue, Gautam Ray, and Andrew B. Whinston point out that investing technology can produce a special level of the stickiness, which is, switching cost [3]. Nemzow argues that a mechanism used to evaluate and promote customer loyalty in traditional marketing named stickiness in e-commerce context [4]. Literature [5] and [6] suggest that site stickiness from a user's perspective is a kind of psychological dependence behavior which forms on the basis of continuant use.

In this paper, referring to [2], we define online consumer stickiness as the following features of online consumers: Due to the psychological commitment to the website deeply held, consumers stick to their preferred website to repeat shopping online in the future regardless of the potential impact of situation leading to the switching behavior and marketing efforts [7]. By means of this construct, analyzing whether a long-term good relationship is formed between online shoppers and special websites, as well as factors influencing their behavior for those consumers with a lot of shopping online experiences; understanding relationships between information technology and people to have insight into the future development trend of network marketing-these are the objectives of this paper.

\section{Literature Review on Online Stickiness}

The related literature on online consumer stickiness is quite less. Most of them focus on two aspects including its definition and factors influencing it.

\subsection{The Definition of Online Stickiness}

From the definitions according to the above-mentioned literature, we can find that: first, there are two types of website stickiness and online users' stickiness. The former is based on a website, which reflects the website's ability and becomes its attribute; and the latter is from a user's perspective, which emphasizes the user's feeling to the website's behavior. No matter what perspective, both have the same objectives to make consumers use the websites often and realize their profits.

Second, a user's stickiness is similar to customer loyalty. Nemzow thinks it as a mechanism to evaluate and promote customer loyalty in e-commerce context [4]. It could come into being in many ways including brand awareness and frequent buyer's plan etc. and it could also make finance obstacles in order to hinder consumers from switching to competitors.

Third, the opposite of the stickiness is switching. In e-commerce, a lot of technology such as personalized web pages, recommendation system, electronic community etc. can be used to add consumers' opportunity cost such as study cost; another artificial cost like online loyalty plan is used to encourage repeat purchase [8] and realizes the objective of website stickiness. So from this point of view, the opposite of it is switching. It can help to create and maintain a competitive capability and a sustainable development. 
Lastly, keeping customer stickiness has changed its direction from originally attaching an importance to developing new products to reserving customers. This is the change of marketing philosophy. It is the current competition situation that makes the change. Good customer stickiness can improve the probability of turning users to consumers and develop products and service brand [4]; good customer stickiness could turn into lower cost to manage existing customers too. It is cheaper to retain loyal and repeating customers than to absorb new customers or to regain those who perhaps have bad experiences before [9].

\subsection{The Influencing Factors on Online Stickiness}

Most of literatures focus on analyzing the influence of website characteristics itself on online consumer stickiness. Judy Chuan-chuan Lin chooses website's content, the context and infrastructure to represent the website's value and studies three factors' influence on online consumer stickiness intention [10]. Bush argues that stickiness (longer and frequent visits) is clearly based on providing unique content and specialized services to vertical market niches [11]. Harvir S. Bansal, et al., use ease of use, information accessibility, product selection, price, transaction duration time, customer service, as well as transport and treatment as website features [12]. Their study finds that these features have direct impacts on online stickiness. In addition to website characteristics, other factors such as consumer's psychological features can influence online stickiness, e.g., customer's attitude towards the website [10], overall satisfaction [12, 13], consumer preferences [14], trust [15], commitment [2], continuance intention [5], habit [16], etc., These studies have shown that these factors' impacts on consumer stickiness are more significant, but there is no agreement on the explanatory power of the impacts. Website features explains only 5\% variance on the stickiness intention [12]; overall satisfaction has the explanatory power of $33 \%$; in Dahui Li, J. Browne Glenn and C. Wetherbe James's study, the stronger explanatory power of commitment and trust reaches up to 70\%[2], and in their another literature, the two factors explain $63 \%$ variance on consumer sticking intention [15].

Through the relevant literature review, influencing factors on online consumer stickiness are studied based on consumers' perception and the factors are analyzed from the relation's perspective. The investigation objects are consumers with many online shopping experiences; the factors in their studies are not consistent; they all include website characteristics and consumption psychology. The reasons for the difference lie in the different research foundations. Some researches lack relevant theoretical basis and only interpret this websitesticking phenomenon commonly in the network marketing; some adopts social psychology theory and marketing theory, such as investment theory, relationship marketing theory etc. Different research basis would lead to different research factors, so the conclusions in these studies are different correspondingly. In addition, researches on user behavior focus on the access to the website or use it, especially legal services website, while researches on shopping website are less.

For those consumers with shopping several times in the same website, whether insisting on sticking to a special website in the future as in the past shows that a relationship between the website and the consumers is set up just like the relationship between people. In the literature, only the study of Dahui Li, J. Browne Glenn, and C. Wetherbe James discusses it [2, 15], but their study doesn't involve the degree of online relationship and whether the relationship during the commitment period exists has not reached a consensus.

In the current network environment of China, the number of online shopping consumers is increasing year by year; there have no lack of long-term website "stickers". But what are the reasons behind the sticking phenomena and whether the relationship exists, related studies are less. 
The organization of this paper is as follows. Section 2 is the literature review. Section 3 presents three relevant streams of research leading to the development of the proposed model. Section 4 develops a research model of online consumer stickiness. Section 5 describes survey procedures, data analysis, and the results. In the final section, we discuss the results and conclude our paper and the implications of our research findings, identify the limitations of the study, and suggest directions for further research.

\section{Theoretical Background}

Given characters of online shopping, it is not only a kind of marketing channel, but also is the use of information technology. Therefore, online consumers continue to visit a particular website, which is similar to the information system users' continuance [15]. Then, theories applied to the information system continuance can also be used in the continuous online shopping. Considering the research object of this paper, Theory of Planned Behavior (TPB) reflecting the basic relations between belief-attitude-intention-behavior is as research basis; Expectation-confirmation theory (ECT) is integrated to reflect the consumer psychology; commitment-trust theory in relationship marketing is considered to understand the formation of transaction relationships, then an online consumer stickiness model is to be built up.

\subsection{Theory of Planned Behavior}

TPB is proposed by Ajzen [17]. It explains and predicts what factors influence individual behavior. It is widely used in all kinds of consumer behavior's study.

The theory includes four kinds of factors shown in Figure 1. They are belief, attitude, intention and behavior. There are three kinds of beliefs, three kinds of attitudes, one behavior intention, and one behavior. These factors' relationships are as follows: behavior attitude, subjective norm and perceived behavioral control directly determine the intention of individual's implementing a behavior; while the former are influenced by the corresponding three beliefs including attitudinal beliefs, normative beliefs and control beliefs. These three determinant factors are the indirect influence factors on the implementation of behaviors. It can be found that the basic relations between beliefs, attitudes, intentions and behaviors are: belief - attitude - intention - behavior. This paper will choose three kinds factors belonging to the former three to study.

\subsection{Expectation-Confirmation Theory}

Oliver puts forward ECT [18]. This theory holds that consumers' satisfaction with prior use of product or service determines their repurchase intention [18]. Consumers have an expectation before use. They form perceptions on its performance via product or service use. After comparing both, they judge whether the perceived performance reach or go beyond their confirmation level. If it is, they will satisfy, or dissatisfy. Then it influences repurchase intention.

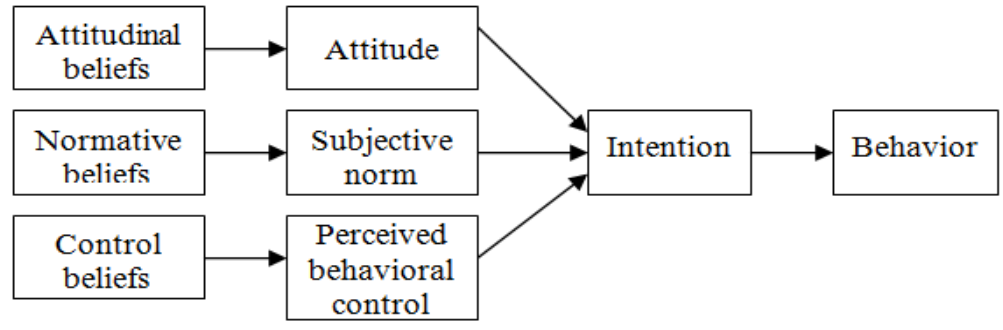

Figure 1. The Theory of Planned Behavior (Adapted from [17]) 
It is widely used in the consumer behavior literature to study consumer satisfaction, postpurchase behavior (e.g., repurchase, complaining), and service marketing in general. E.g., Oliver has used this theory to demonstrate the automobile repurchase [19]; Swan and Trawick have applied it to explain restaurant service, et al., [20]. Figure 2 illustrates key constructs and relationships in ECT.

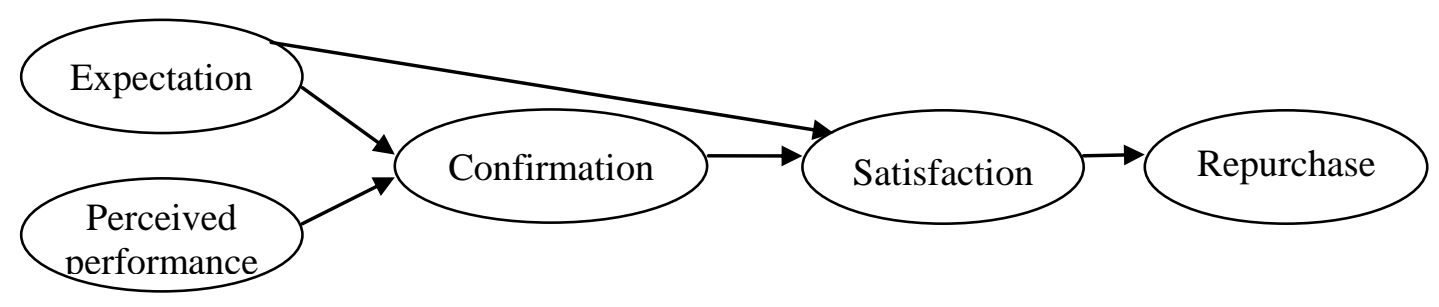

Figure 2. Expectation-Confirmation Theory [19]

This theory can not only predict over a wide range of product repurchase and service continuance contexts but also can be used in information system (IS) environment. Bhattacherjee studies the IS continuance according to this theory and proves its predictive ability [21]. So the relationship between confirmation and satisfaction in the online context can be predicted.

Confirmation is a cognitive belief derived from prior site use. In addition, it influences subsequent use via the satisfaction (affect) and intention constructs. This paper uses the nature of confirmation as reference.

This paper uses stickiness intention to replace repurchase intention in online shopping. Consumers' sticking to a website means often visiting and repurchasing on the same site during a long time and shows their preference and trust to the website.

Overall satisfaction is used in explaining the psychological feeling after consumers experience the purchase process online for many times. It is a kind of attitude estimation. Does the experience bring satisfaction or dissatisfaction to consumers? Overall satisfaction measures it. So we consider it as an attitude to explain the emotional reaction consumers have on the website and its services during the whole process.

\subsection{Commitment-Trust Theory}

The theory is important in relationship marketing presented by Morgan \& Hunt [22]. The theory shows that trust is positively associated with commitment typically in B2B and B2C relationships. It is concerned with the exchange of long-term relationships between a company and its partners. Commitment and trust are the most prominent factors in forming, developing, maintaining relationships between people and relationship marketing. They are critical to distinguish the relationship transaction and economic transactions. It is necessary for the formation of a positive relationship behavior and motivation [22]. If the interaction between people and websites is compared to social interaction between people in the network context, the two factors are very important to understand the relationship between online consumers and websites (e-vendors), as well as the reasons for sticking to the websites. It may be also used in online relationships.

In the network context, trust is called online trust. It has two types during different stages of shopping online according to McKnight [23], one is initial trust, and the other is ongoing trust. The former is used when consumers first shop online and form the initial trust belief in websites and its vendors. The latter forms after consumers shop online many times and it will 
encourage them to continue shopping in the same website in the future. In this paper, ongoing trust is suitable to describe the belief in the sticking stage.

Commitment has been defined as a persistent desire to maintain valuable relations [24], so it can be regarded as a kind of attitude. Commitment to a relationship explains an individual's positive attitude toward a social or business relationship and his motivation to remain in the relationship [22]. If a kind of relationship forms between a consumer and a special website, commitment will play an important role. According to the commitment-trust theory, ongoing trust will influence significantly on commitment to the online relationship.

\section{A Research Model on Online Consumer Stickiness}

In this section, considering the characteristics of online shoppers with repeated experience and the expected relationship's formation, on the basis of the theory above, we establish a model on online consumer stickiness as shown in Figure 3.

Belief

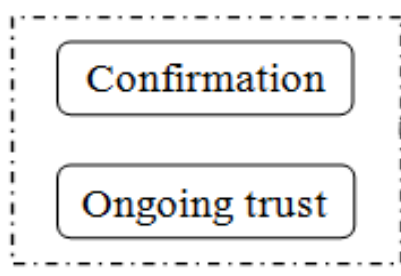

Attitude

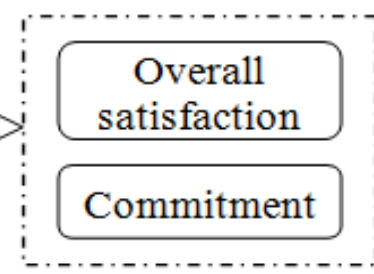

\section{$\underline{\text { Intention }}$}

Stickiness

intention

Figure 3. The Proposed Model of Online Consumer Stickiness

Figure 3 shows the relationships between belief, attitude and intention. Referred to TPB, belief has a positive effect on attitude, and attitude has a positive effect on intention. Confirmation and ongoing trust are looked as belief; overall satisfaction and commitment are as attitude; stickiness intention is the probability that consumers continue to use a special website to shop online.

Based on the above theory, the following hypotheses can be proposed:

H1: consumers' extent of confirmation is positively associated with their overall satisfaction with online shopping.

$\mathrm{H} 2$ : consumers' extent of confirmation is positively associated with their commitment to online shopping.

H3: consumers' ongoing trust is positively associated with their overall satisfaction with online shopping.

H4: consumers' ongoing trust is positively associated with their commitment to online shopping.

H5: consumers' overall satisfaction is positively associated with their online stickiness intention.

H6: consumers' commitment to online shopping is positively associated with their online stickiness intention.

\section{Method and Results}

\subsection{Data Collection}

To test the research model, we used the survey method to collect data. We examined the relationship between online consumers and a range of online e-vendors who provided 
different types of products to consumers through the Internet. The survey was carried out to undergraduate students at a large research university. The student sample is a typical segment of Internet users and has been widely used in previous studies [25].

In the data collection process, the respondents were asked through questionnaire to evaluate the last e-commerce website from which they had purchased something for many times.

After initial design of the questionnaire, pre-test was conducted to modify it. According to the test results and the experts' advice, the question items were adjusted, and then the last questionnaire to be used was determined. The questionnaire included three parts: the first part was the objective of the survey; the second part was the items of all factors in the model; the third part was the demographics such as gender, age, education level, monthly income, online shopping frequency, etc.

400 paper-based questionnaires were issued to undergraduate students from different classes. The response rate was $83.75 \%$ and 335 questionnaires were available.

\section{Table 1. Demographics of the Respondents}

\begin{tabular}{|c|c|c|c|}
\hline Demographics & $\begin{array}{c}\text { Frequency } \\
(\%)\end{array}$ & $\begin{array}{c}\text { Frequency } \\
(\%)\end{array}$ \\
\hline $\begin{array}{c}\text { Gender: } \\
\text { male }\end{array}$ & 57.4 & $\begin{array}{c}\text { Demographics } \\
\text { High school (secondary) and below }\end{array}$ & 15.8 \\
female & 42.6 & $\begin{array}{c}\text { University (including college) } \\
\text { Master degree or above }\end{array}$ & 64.5 \\
Age: & & Monthly income(Yuan): & 19.7 \\
$<20$ & 21.2 & $\leq 500$ & \\
$20-30$ & 58.7 & $501-1000$ & 19.9 \\
$30-40$ & 19.1 & $1001-2000$ & 24.2 \\
$\geq 40$ & 1.0 & $2001-3000$ & 21.4 \\
Online shopping & & $3001-5000$ & 14.5 \\
experience: & 46.3 & $>5000$ & 18.9 \\
$<1$ & 43.3 & Access frequency: & 1.1 \\
$1 \sim 3$ year & 2.6 & Occasionally & 2.8 \\
$4-\sim 6$ year & 0.3 & Often & 62.7 \\
$7 \sim 9$ year & 0 & Everyday & 34.5 \\
$\geq 9$ & & & \\
\hline
\end{tabular}

The respondents ranged in age from 19 to 49 , the average age is 25 , of which $57.4 \%$ are male, $42.6 \%$ are female. Educational levels ranged from graduates to doctoral degrees. The respondents with monthly income below 500 Yuan accounted for 19.9\%; those with 5012000 Yuan were the majority, accounting for $45.6 \%$. Most respondents (46.3\%) had online shopping experience with 1 year, followed by the 1-3 years (43.3\%). Both accounted for up to nearly $90 \%$. The respondents had online accounts for two months to three years (mean of eight months). The details are shown in Table 1.

\subsection{Instrument Construction}

Five constructs were measured in this study: stickiness intention, overall satisfaction, confirmation, ongoing trust, and commitment. Constructs were measured using multiple-item scales, drawn from pre- validated measures in IS use or marketing or ECT research (wherever possible), and reworded to relate specifically to the context of online use. Overall satisfaction items were based on seven-point semantic differential scales. All remaining scale items used 
seven-point Likert scales anchored between "strongly disagree" and "strongly agree." Table 2 provided operational definitions and sources for these constructs.

\subsection{Data Analysis and Results}

SPSS17.0 and Lisral 8.70 were used to analyze data and SEM (Structure Equation Model) was used to test the model. Construct reliability and validity were estimated. EFA (Exploratory Factor Analysis) and CFA (Certified Factor Analysis) were made. The factor loadings and Cronbach $\alpha$ were shown in Table 3. Factor loadings and average variance extracted (AVE) demonstrated adequate convergent validity. Comparing inter construct correlations with the square roots of AVE (Average Variance Extracted) provided positive support for discriminant validity. They were shown in Table 4. Both item reliability and composite reliability in our study were above the suggested values.

Table 2. Measurement and Source of Constructs

\begin{tabular}{|c|c|c|c|}
\hline Construct & Operational definition & Measurement contents & Reference source \\
\hline $\begin{array}{l}\text { Stickiness } \\
\text { intention }\end{array}$ & $\begin{array}{l}\text { Consumers' intention } \\
\text { to continue to } \\
\text { repurchase on their } \\
\text { preference website no } \\
\text { matter what marketing } \\
\text { effort or switching } \\
\text { costs. }\end{array}$ & $\begin{array}{l}\text { Planning for the future to } \\
\text { continue shopping in the } \\
\text { website; is expected in the } \\
\text { future in the shopping } \\
\text { website; the transaction } \\
\text { possibility to continue with } \\
\text { the online retailer in the near } \\
\text { future. }\end{array}$ & $\begin{array}{l}\mathrm{Li}, \text { Browne, and } \\
\text { Wetherbe [2] } \\
\text { Liao, Palvia and Lin } \\
{[26]}\end{array}$ \\
\hline $\begin{array}{c}\text { Overall } \\
\text { satisfaction }\end{array}$ & $\begin{array}{l}\text { Consumer's emotional } \\
\text { responses generating } \\
\text { from the long-term } \\
\text { trading experience } \\
\text { with the website based } \\
\text { on past transactions. }\end{array}$ & $\begin{array}{l}\text { The degree of feeling happy, } \\
\text { pleasure, satisfied with the } \\
\text { whole transaction process } \\
\text { with the website. }\end{array}$ & $\begin{array}{l}\text { Spreng, MacKenzie } \\
\text { and Olshavsky [27] }\end{array}$ \\
\hline Confirmation & $\begin{array}{l}\text { Consumers' perception } \\
\text { of the congruence } \\
\text { between expectation of } \\
\text { transaction and its } \\
\text { actual performance. }\end{array}$ & $\begin{array}{l}\text { My experience with the } \\
\text { website was better than what } \\
\text { lexpected; The service level } \\
\text { provided by the website was } \\
\text { better than what } 1 \text { expected. } \\
\text { Overall, most of my } \\
\text { expectations from online } \\
\text { shopping were confirmed. }\end{array}$ & Bhattacherjee [21] \\
\hline $\begin{array}{l}\text { Ongoing } \\
\text { trust }\end{array}$ & $\begin{array}{l}\text { Consumers' subjective } \\
\text { beliefs in the website } \\
\text { to behave in a reliable } \\
\text { way in trade. }\end{array}$ & $\begin{array}{l}\text { Whether the site has the } \\
\text { ability to do diligence work, } \\
\text { to fulfill its commitments } \\
\text { and guarantee obligations, } \\
\text { are worthy of trust. }\end{array}$ & Gefen [25] \\
\hline Commitment & $\begin{array}{l}\text { Consumers' persistent } \\
\text { desire to maintain a } \\
\text { valuable relationship } \\
\text { with a website }\end{array}$ & $\begin{array}{l}\text { Online consumers like to } \\
\text { discuss with others the } \\
\text { website's goodness; they are } \\
\text { easy to rely on the website; } \\
\text { if stop using the website, } \\
\text { whether consumers will have } \\
\text { losses. }\end{array}$ & $\begin{array}{l}\text { Allen and Meyer } \\
\text { [28]; } \\
\text { Li, Browne and } \\
\text { Wetherbe [2] }\end{array}$ \\
\hline
\end{tabular}


Table 3. The Factor Loadings and Reliability Analysis

\begin{tabular}{|c|c|c|c|c|}
\hline Construct & Item & Std. Loading & Cronbach $\alpha$ & $\begin{array}{l}\text { Composite } \\
\text { Reliability }\end{array}$ \\
\hline Stickiness intention & $\begin{array}{l}\text { STI1 } \\
\text { STI2 } \\
\text { STI3 }\end{array}$ & $\begin{array}{l}.87 \\
.90 \\
.79\end{array}$ & .90 & .88 \\
\hline Confirmation & $\begin{array}{l}\text { CON1 } \\
\text { CON2 } \\
\text { CON3 }\end{array}$ & $\begin{array}{l}.82 \\
.79 \\
.80\end{array}$ & .84 & .85 \\
\hline Ongoing trust & $\begin{array}{l}\text { TRU1 } \\
\text { TRU2 } \\
\text { TRU3 }\end{array}$ & $\begin{array}{l}.75 \\
.77 \\
.74\end{array}$ & .81 & .90 \\
\hline Overall satisfaction & $\begin{array}{l}\text { OSA1 } \\
\text { OSA2 } \\
\text { OSA3 }\end{array}$ & $\begin{array}{l}.71 \\
.89 \\
.81 \\
\end{array}$ & .85 & .84 \\
\hline Commitment & $\begin{array}{l}\text { COM1 } \\
\text { COM2 } \\
\text { COM3 }\end{array}$ & $\begin{array}{l}.65 \\
.72 \\
.80\end{array}$ & .86 & .91 \\
\hline
\end{tabular}

Notes: (CFA) fit indices: Chi square=205.48, (df =80, $\mathrm{p}<.001$ ); RMSEA=.0069; GFI=.92; $A G F I=.89$; $\mathrm{NFI}=.96 ; \mathrm{NNFI}=.96 ; \mathrm{CFI}=.97$

The research hypotheses were tested as shown in Figure 4. The fit indices showed an acceptable fit degree of the structural model with the data. The variance explained was $48 \%$ for stickiness intention, $45 \%$ for commitment, and $51 \%$ for overall satisfaction. Obviously all the hypotheses were verified except $\mathrm{H} 2$, i.e., the relationship between confirmation and commitment was not supported by the data.

Table 4. Inter Construct Correlations and AVE

\begin{tabular}{|c|c|c|c|c|c|}
\hline Construct & $\begin{array}{c}\text { Stickiness } \\
\text { intention }\end{array}$ & Confirmation & $\begin{array}{c}\text { Overall } \\
\text { satisfaction }\end{array}$ & $\begin{array}{c}\text { Ongoing } \\
\text { trust }\end{array}$ & Commitment \\
\hline $\begin{array}{c}\text { Stickiness } \\
\text { intention }\end{array}$ & .781 & & & & \\
\hline Confirmation & $.516(* *)$ & .861 & & & \\
\hline $\begin{array}{c}\text { Overall } \\
\text { satisfaction }\end{array}$ & $.481(* *)$ & $.652(* *)$ & .815 & & \\
\hline Ongoing trust & $.433(* *)$ & $.521\left(^{* *}\right)$ & $.456(* *)$ & .826 & .891 \\
\hline Commitment & $.561(* *)$ & $.646(* *)$ & $.606(* *)$ & $.410(*)$ & .891 \\
\hline
\end{tabular}

Notes: Square root of average variance extracted is shown on the diagonal of the matrix. 


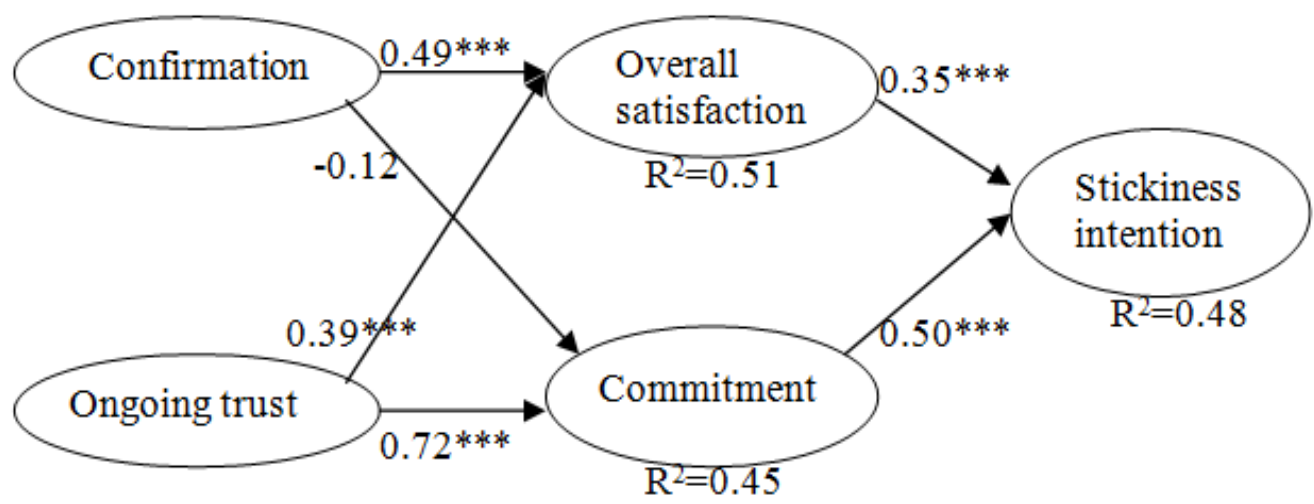

Notes: Chi square $=208.58(\mathrm{df}=83, \mathrm{p}<0.001)$; RMSEA $=0.068 ; \mathrm{GFI}=.92 ; \mathrm{AGFI}=.89 ; \mathrm{NFI}=.95$; $\mathrm{NNFI}=.96 ; \mathrm{CFI}=.97^{* *} \mathrm{p}<0.01 ;{ }^{* *} \mathrm{p}<0.001$.

\section{Figure 4. The Model Testing Results}

\section{Discussion and Conclusions}

\subsection{Discussion of Results}

According to the test results, both confirmation and ongoing trust have positive and significant effects on overall satisfaction $(\mathrm{H} 1$ and $\mathrm{H} 3)$, and both are the stronger predictor of it $\left(\mathrm{R}^{2}=0.51\right)$. On one hand, if a website's performance can meets consumers' expectations based on their repeat shopping experience, consumers will feel satisfied with the transaction as well as e-vendors. On the other hand, if consumers have developed ongoing trust due to their familiarity, they will also give higher satisfaction to the website and its e-vendors. So no matter whether it is initial or repeat shopping online, trust is a very important factor.

In addition, the relationship between ongoing trust and commitment is also verified in online repeat shopping context $(\mathrm{H} 4)$ and the prediction power is stronger $\left(\mathrm{R}^{2}=0.45\right)$. It is consistent with previous studies [22]. This suggests that the more an individual trusts the relationship with the website or the e-vendor, the more likely he or she is to be attached to the relationship. This also means that long-term relationship between consumers and the website can be developed just as in the physical environment. Consumers have the intention to continue to maintain the transaction relationship. So websites can realize their objective of sticking to customers.

But the study doesn't give support to the relationship between confirmation and commitment (H2). In fact, it hasn't been studied in other literature. It is found that confirmation has the indirect effect on the commitment through satisfaction and trust. Perhaps it is the reason.

The study supports that commitment is a slightly stronger predictor of stickiness intention (H6) than overall satisfaction (H5). Both have higher prediction $\left(\mathrm{R}^{2}=48 \%\right)$. This finding shows the role of commitment and further verifies the relationship does exist between consumers and websites as well as their representative e-vendors.

\subsection{Conclusions}

The goal of this paper is to identify the factors influencing the online stickiness intention and to understand the long-term transaction relationship developed between consumers and websites or e-vendors. Although online environment is different from physical environment, products cannot be touched or felt face to face; it can also produce deep trust, that is, ongoing 
trust or commitment among them. Consumers' overall satisfaction and commitment are two significant factors to influence stickiness intention. Consumers' ongoing trust has a significant positive effect on consumers' commitment to online shopping. Confirmation and ongoing trust significantly influence consumers' overall satisfaction.

Satisfaction is viewed as the key to building and retaining a loyal base of long-term consumers $[19,21]$. "Investing in customer satisfaction is like taking out an insurance policy." [29, p. 160]. Trust and commitment are also looked as the symbol of long-term relationship formation. This study proves it is true. Therefore, e-vendors should realize this and should pay more attention on the development of ongoing trust and try their best to make consumers satisfied by meeting their expectation.

This study has some limitations. One is the subject. University students as sample are not suitable to extend the conclusion to other groups. So the future study can survey other adult group; the other is lack of more factors. This study only tests several ones. There are still other factors to influence consumer stickiness intention. In the future, emotional factors such as perceived enjoyment or efficacy, et al., can be studied. In addition, demographics are also suggested to study in the future to investigate the effects of sex, age, education level, online experience, etc.

In conclusion, sticking to a special website not only means that consumers like shopping on the website but also means a kind of psychological reliability appears on consumers and evendors. It will encourage e-vendors to provide better products or service for consumers and promote the quick development of online transactions.

\section{Acknowledgements}

The research is supported by National Natural Science Foundation of China (NSFC) under Grant No.71172046, MOE (Ministry of Education in China) Youth Fund Project of Humanities and Social Sciences (No.13YJC630162), Shandong Province Natural Science Foundation (No.ZR2011GL018), A Project of Shandong Province Higher Education Humanities and Social Sciences Program (No.J11WG65), and Shandong Province Social Sciences Youth Project (No.13DGLJ04).

\section{References}

[1] C. R.Zott and J. Donlevy, "Strategies for value creation in e-commerce: best practice in European", European Management Journal, vol. 6, no. 18, (2000).

[2] D. Li, J. B. Glenn and C. W. James, "Why do Internet users stick with a specific web site", A relationship perspective. International Journal of Electronic Commerce, vol. 4, no. 10, (2006).

[3] L. Xue, G. Ray and A. B. Whinston, "Strategic investment in switching cost: an integrated customer acquisition and retention perspective", International Journal of Electronic Commerce, vol. 1, no. 11, (2006).

[4] M. Nemzow, "Ecommerce stickiness for customer retention", Journal of Internet Banking and Commerce, vol. 1 , no. 4, (1999).

[5] J. Xue, Q. Zhao and L. Wei, "Research on antecedents of online shopping stickiness", Finance and Trade Research, vol. 4, (2012).

[6] Q. Zhao, Z. Li and J. Xue, “Online users' stickiness behavior formation mechanism and empirical Analysis", Information Studies: Theory \& Application, vol. 10, no. 35, (2012).

[7] H. Wang, "Review of online stickiness research from marketing perspective", Productivity Research, vol. 6, (2013).

[8] G. Shaffer and Z. J. Zhang, "Competitive one-to-one promotions", Management Science, vol. 9, no. 48, (2008).

[9] K. Guenther, "Pull up a chair and stay awhile: strategies to maximize site stickiness", Web Site Management, vol. 1, (2009).

[10] J. Chuan-Chuan Lin, "Online stickiness: Its antecedents and effect on purchasing intention", Behavior \& Information Technology, vol. 6, no. 26, (2007). 
[11] E. Bush, "Company to expand strategic alliance in key vertical markets by helping partners increase portal stickiness and community development", Business Wire, vol. 3, (1999).

[12] S. Harvir, M. Bansal, H. G. Gordon, S. S. Dikolli and K. L. Sedatole, "Relating e-satisfaction to behavioral outcomes: an empirical study", Journal of Services Marketing, vol. 4, no. 18, (2004).

[13] K. Mohamed, M. Limayem and V. Liu, "Online consumer stickiness: a longitudinal study", Journal of Global Information Management, vol. 3, no. 10, (2002).

[14] K. Sri Hastuti, "Modeling Online Retailer Customer Preference and Stickiness: A Mediated Structural Equation Model”, Fourth Pacific Asia Conference on Information Systems, (2004) July, pp. 8-11, Hong Kong, China.

[15] D. Li, G. J. Browne, J. C. Wetherbe, “Online consumer's switching behavior: a buyer-seller relationship perspective", Journal of Electronic Commerce in Organizations, vol. 1, no. 5, (2007).

[16] H. Wang, "Research on Online Consumer Stickiness", Shandong University, Jinan, Shandong, (2009).

[17] I. Ajzen, "The theory of planned behavior", Organizational Behavior and Human Decision Processes, vol. 2, no. 50, (1991).

[18] R. L. Oliver, "A cognitive model for the antecedents and consequences of satisfaction”, Journal of Marketing Research, vol. 4, no. 17, (1980).

[19] R. L. Oliver, "Cognitive, affective, and attribute bases of the satisfaction response", Journal of Consumer Research, vol. 3, no. 20, (1993).

[20] J. E. Swan and I. F. Trawick, "Disconfirmation of expectations and satisfaction with a retail service", Joumal of Retailing, vol. 3, no. 57, (1981).

[21] B. Anol, "Understanding information systems continuance: an expectation confirmation model", MIS Quarterly, vol. 5, no. 32, (2001).

[22] R. M. Morgan and S. D. Hunt, "The commitment-trust theory of relationship marketing", Journal of Marketing, vol. 3, no. 58, (1994).

[23] D. H. McKnight and N. L. Chervany, "What trust means in e-commerce customer relationships: an interdisciplinary conceptual typology", International Journal of Electronic Commerce, vol. 2, no. 6, (2002).

[24] C. Moorman, G. Zaltman and R. Deshpande, "Relationships between providers and users of market research: the dynamics of trust within and between organizations", Journal of Marketing Research, vol. 3, no. 29 (1992).

[25] D. Gefen, “TAM or just plain habit: A look at experienced online shoppers”, Journal of End User Computing, vol. 3, no. 15, (2003).

[26] C. Liao, P. Prashant and L. Hong-Nan, "The roles of habit and web site quality in e-commerce", International Journal of Information Management, vol. 6, no. 26, (2006).

[27] R. A. Spreng, S. B. MacKenzie and R. W. Olshavsky, "A reexamination of the determinants of consumer satisfaction", Journal of Marketing, vol. 3, no. 60, (1996).

[28] N. J. Allen and J. P. Meyer, "The measurement and antecedents of affective, continuance, and normative commitment to the organization", Journal of Occupational Psychology, vol. 1, no. 63, (1990).

[29] E. W. Anderson and M. W. Sullivan, "The antecedents and consequences of customer satisfaction for firms", Marketing Science, vol. 2, no. 12, (1993).

\section{Author}

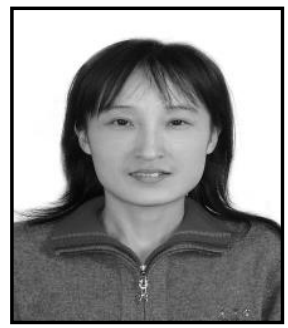

Haiping Wang, she received her M. Acc. from East China Jiaotong University (2003) and $\mathrm{PhD}$ in Business Management (2009) from Shandong University. Now she is an associate professor at School of Insurance, Shandong University of Finance and Economics. Her current research interests include different aspects of online consumption and ecommerce. 